\title{
Highlight report: acetaminophen hepatotoxicity
}

\author{
Ahmed Ghallab ${ }^{1}$
}

Published online: 28 November 2015

(C) Springer-Verlag Berlin Heidelberg 2015

Acetaminophen (APAP) represents the leading cause of liver failure in Europe (Lancaster et al. 2015). Much effort has been invested to gain a better understanding of the molecular mechanisms of APAP hepatotoxicity (Saito et al. 2010; Kon et al. 2004; Hwang et al. 2015; Sjogren et al. 2014; Schyschka et al. 2013; Singh et al. 2013) and to identify biomarkers of APAP overdose (McGill et al. 2014; Beger et al. 2015). APAP is known to be metabolically activated to the reactive $\mathrm{N}$-acetyl-p-benzoquinone imine (NAPQI), which forms protein adducts including mitochondrial proteins leading to mitochondrial oxidative stress (Ramachandran et al. 2013; Cohen et al. 1997). As a consequence c-jun N-terminal kinase is translocated to the mitochondria, which enhances generation of reactive oxygen species (Ramachandran et al. 2013; Hanawa et al. 2008; Saito et al. 2010). This may lead to opening of the mitochondrial membrane transition pore and cause a form of cell death which differs from classical apoptosis and has been named 'necroptosis' (Kon et al. 2004; Gujral et al. 2002; Ni et al. 2012). Although cytochrome c is released from the mitochondria, for so far unknown reasons apoptotic cell death is not induced (Gujral et al. 2002; Lawson et al. 1999; Williams et al. 2010). In a recent issue of the Archives of Toxicology, Lancaster and colleagues have published an updated review on diagnosis and clinical management of APAP-induced liver failure (Lancaster et al. 2015). One of the most urgent clinical research fields seems to be the identification of biomarkers that predict more reliably whether a patient is in need of treatment

Ahmed Ghallab

Ghallab@vet.svu.edu.eg

1 Forensic Medicine and Toxicology Department, Faculty of Veterinary Medicine, South Valley University, Qena, Egypt and hospitalization. Lancaster and colleagues discuss a case in which a patient died, who did not receive $N$-acetylcysteine according to the ' $200 \mu \mathrm{g} / \mathrm{ml}$ line'. Therefore, it became standard in the UK to treat any patient with serum APAP equivalent to only $100 \mu \mathrm{g} / \mathrm{ml}$ at $4 \mathrm{~h}$ after intoxication (Lancaster et al. 2015). However, because the majority of patients with an overdose do not show such serve consequences, the new UK standard means that one life is saved every 2 years associated with costs of 17.3 million euros per saved life. This underlines the urgent need of better predictive biomarkers (Lancaster et al. 2015).

The article of Lancaster et al. (2015) is also of relevance for the field of alternative methods (Hammad 2013; Ghallab 2013, 2014a, b; Reif 2014a, b; Godoy 2011). Currently, intensive research activities are ongoing to establish in vitro systems particularly for hepatotoxicity (Grinberg et al. 2014; Ramaiahgari et al. 2014; Rodrigues et al. 2013; Schug et al. 2013), nephrotoxicity (Sanchez-Niño et al. 2014; Fujiki et al. 2013; 2014), neurotoxicity (Barbosa et al. 2014; Sisnaiske et al. 2014; Frimat et al. 2010) and developmental toxicity (Krug et al. 2013; Rempel et al. 2015; Balmer et al. 2014; Zimmer et al. 2014). For validation of in vitro systems with hepatocytes APAP represents a popular reference compound (Jennings et al. 2014; Hengstler et al. 2014). However, it can often be observed that in vitro studies used very high APAP concentrations in the range of $10 \mathrm{mM}$ or even higher. The review of Lancaster et al. (2015) reminds us of the time-honored ' $200 \mu \mathrm{g} / \mathrm{ml}$ line', which means that a serum concentration of $200 \mu \mathrm{g}$ APAP/ml $4 \mathrm{~h}$ after oral uptake represents a threshold above which the risk of acute liver failure significantly increases. Considering the molecular weight of APAP of $151.16 \mathrm{~g} /$ mol this corresponds to a threshold of $1.3 \mathrm{mM}$. It should also be considered that due to a half-life of $1-4 \mathrm{~h}$ in human, concentrations in vivo decrease much faster than in vitro. 
Most likely the reason for resistance of cultivated hepatocytes to APAP is decreased expression CYP2E1 and further cytochrome P450 enzymes involved in APAP metabolic activation. It is well known that the isolation and cultivation stress lead to a rapid decrease in metabolizing enzymes in human hepatocytes (Godoy et al. 2013, 2015) and even more in rodents (Zellmer et al. 2010; Heise et al. 2012; Godoy et al. 2009). Because of the relatively large discrepancy between APAP concentrations in vivo and higher concentrations chosen in many in vitro studies, it should be interpreted with caution, whether mechanisms observed in vitro at $10 \mathrm{mM}$ and higher actually represent the in vivo situation.

\section{References}

Balmer NV, Klima S, Rempel E, Ivanova VN, Kolde R, Weng MK, Meganathan K, Henry M, Sachinidis A, Berthold MR, Hengstler JG, Rahnenführer J, Waldmann T, Leist M (2014) From transient transcriptome responses to disturbed neurodevelopment: role of histone acetylation and methylation as epigenetic switch between reversible and irreversible drug effects. Arch Toxicol 88(7):1451-1468. doi:10.1007/s00204-014-1279-6

Barbosa DJ, Capela JP, Silva R, Ferreira LM, Branco PS, Fernandes E, Bastos ML, Carvalho F (2014) "Ecstasy"-induced toxicity in SH-SY5Y differentiated cells: role of hyperthermia and metabolites. Arch Toxicol 88(2):515-531. doi:10.1007/ s00204-013-1147-9

Beger RD, Bhattacharyya S, Yang X, Gill PS, Schnackenberg LK, Sun J, James LP (2015) Translational biomarkers of acetaminophen-induced acute liver injury. Arch Toxicol 89(9):14971522. doi:10.1007/s00204-015-1519-4

Cohen SD, Pumford NR, Khairallah EA, Boekelheide K, Pohl LR, Amouzadeh HR, Hinson JA (1997) Selective protein covalent binding and target organ toxicity. Toxicol Appl Pharmacol 143(1): $1-12$

Frimat JP, Sisnaiske J, Subbiah S, Menne H, Godoy P, Lampen P, Leist M, Franzke J, Hengstler JG, van Thriel C, West J (2010) The network formation assay: a spatially standardized neurite outgrowth analytical display for neurotoxicity screening. Lab Chip 10(6):701-709. doi:10.1039/b922193j

Fujiki K, Inamura H, Matsuoka M (2013) Phosphorylation of FOXO3a by PI3 K/Akt pathway in HK-2 renal proximal tubular epithelial cells exposed to cadmium. Arch Toxicol 87(12):21192127. doi:10.1007/s00204-013-1077-6

Fujiki K, Inamura H, Matsuoka M (2014) PI3 K signaling mediates diverse regulation of ATF4 expression for the survival of HK-2 cells exposed to cadmium. Arch Toxicol 88(2):403-414. doi:10.1007/s00204-013-1129-y

Ghallab A (2013) In vitro test systems and their limitations. EXCLI J 12:1024-1026

Ghallab A (2014a) Human non-parenchymal liver cells for co-cultivation systems. EXCLI J 13:1295-1296

Ghallab A (2014b) The rediscovery of HepG2 cells for prediction of drug induced liver injury (DILI). EXCLI J 13:1286-1288

Godoy P (2011) Hepatotoxicity. EXCLI J 10:124-127

Godoy P, Hengstler JG, Ilkavets I, Meyer C, Bachmann A, Müller A, Tuschl G, Mueller SO, Dooley S (2009) Extracellular matrix modulates sensitivity of hepatocytes to fibroblastoid dedifferentiation and transforming growth factor beta-induced apoptosis. Hepatology 49(6):2031-2043
Godoy P, Hewitt NJ, Albrecht U et al (2013) Recent advances in 2D and $3 \mathrm{D}$ in vitro systems using primary hepatocytes, alternative hepatocyte sources and non-parenchymal liver cells and their use in investigating mechanisms of hepatotoxicity, cell signaling and ADME. Arch Toxicol 87(8):1315-1530

Godoy P, Schmidt-Heck W, Natarajan K, Lucendo-Villarin B, Szkolnicka D, Asplund A, Bjorquist P, Widera A, Stoeber R, Campos G, Hammad S, Sachinidis A, Damm G, Weiss TS, Nussler A, Synnergren J, Edlund K, Küppers-Munther B, Hay D, Hengstler JG (2015) Gene networks and transcription factor motifs defining the differentiation of stem cells into hepatocyte-like cells. J Hepatol. doi:10.1016/j.jhep.2015.05.013

Grinberg M, Stöber RM, Edlund K, Rempel E, Godoy P, Reif R, Widera A, Madjar K, Schmidt-Heck W, Marchan R, Sachinidis A, Spitkovsky D, Hescheler J, Carmo H, Arbo MD, van de Water B, Wink S, Vinken M, Rogiers V, Escher S, Hardy B, Mitic D, Myatt G, Waldmann T, Mardinoglu A, Damm G, Seehofer D, Nüssler A, Weiss TS, Oberemm A, Lampen A, Schaap MM, Luijten M, van Steeg H, Thasler WE, Kleinjans JC, Stierum RH, Leist M, Rahnenführer J, Hengstler JG (2014) Toxicogenomics directory of chemically exposed human hepatocytes. Arch Toxicol 88(12):2261-2287

Gujral JS, Knight TR, Farhood A, Bajt ML, Jaeschke H (2002) Mode of cell death after acetaminophen overdose in mice: apoptosis or oncotic necrosis? Toxicol Sci 67(2):322-328

Hammad S (2013) Advances in 2D and 3D in vitro systems for hepatotoxicity testing. EXCLI J 12:993-996

Hanawa N, Shinohara M, Saberi B, Gaarde WA, Han D, Kaplowitz N (2008) Role of JNK translocation to mitochondria leading to inhibition of mitochondria bioenergetics in acetaminopheninduced liver injury. J Biol Chem 283(20):13565-13577. doi:10.1074/jbc.M708916200

Heise T, Schug M, Storm D, Ellinger-Ziegelbauer H, Ahr HJ, Hellwig B, Rahnenfuhrer J, Ghallab A, Guenther G, Sisnaiske J, Reif R, Godoy P, Mielke H, Gundert-Remy U, Lampen A, Oberemm A, Hengstler JG (2012) In vitro-in vivo correlation of gene expression alterations induced by liver carcinogens. Curr Med Chem 19(11):1721-1730

Hengstler JG, Marchan R, Bolt HM (2014) Standard compounds for establishment of in vitro test systems. Arch Toxicol 88(12):20832084. doi:10.1007/s00204-014-1398-0

Hwang JH, Kim YH, Noh JR, Gang GT, Kim KS, Chung HK, Tadi $\mathrm{S}$, Yim YH, Shong M, Lee $\mathrm{CH}$ (2015) The protective role of $\mathrm{NAD}(\mathrm{P}) \mathrm{H}$ :quinone oxidoreductase 1 on acetaminopheninduced liver injury is associated with prevention of adenosine triphosphate depletion and improvement of mitochondrial dysfunction. Arch Toxicol 89(11):2159-2166. doi:10.1007/ s00204-014-1340-5

Jennings P, Schwarz M, Landesmann B, Maggioni S, Goumenou M, Bower D, Leonard MO, Wiseman JS (2014) SEURAT-1 liver gold reference compounds: a mechanism-based review. Arch Toxicol 88(12):2099-2133. doi:10.1007/s00204-014-1410-8

Kon K, Kim JS, Jaeschke H, Lemasters JJ (2004) Mitochondrial permeability transition in acetaminophen-induced necrosis and apoptosis of cultured mouse hepatocytes. Hepatology 40(5):1170-1179

Krug AK, Kolde R, Gaspar JA, Rempel E, Balmer NV, Meganathan K, Vojnits K, Baquié M, Waldmann T, Ensenat-Waser R, Jagtap S, Evans RM, Julien S, Peterson H, Zagoura D, Kadereit S, Gerhard D, Sotiriadou I, Heke M, Natarajan K, Henry M, Winkler J, Marchan R, Stoppini L, Bosgra S, Westerhout J, Verwei M, Vilo J, Kortenkamp A, Hescheler J, Hothorn L, Bremer S, van Thriel C, Krause KH, Hengstler JG, Rahnenführer J, Leist M, Sachinidis A (2013) Human embryonic stem cell-derived test systems for developmental neurotoxicity: a transcriptomics approach. Arch Toxicol 87(1):123-143 
Lancaster EM, Hiatt JR, Zarrinpar A (2015) Acetaminophen hepatotoxicity: an updated review. Arch Toxicol 89(2):193-199. doi:10.1007/s00204-014-1432-2

Lawson JA, Fisher MA, Simmons CA, Farhood A, Jaeschke H (1999) Inhibition of Fas receptor (CD95)-induced hepatic caspase activation and apoptosis by acetaminophen in mice. Toxicol Appl Pharmacol 156(3):179-186

McGill MR, Li F, Sharpe MR, Williams CD, Curry SC, Ma X, Jaeschke H (2014) Circulating acylcarnitines as biomarkers of mitochondrial dysfunction after acetaminophen overdose in mice and humans. Arch Toxicol 88(2):391-401. doi:10.1007/ s00204-013-1118-1

Ni HM, Bockus A, Boggess N, Jaeschke H, Ding WX (2012) Activation of autophagy protects against acetaminophen-induced hepatotoxicity. Hepatology 55(1):222-232. doi:10.1002/hep.24690

Ramachandran A, McGill MR, Xie Y, Ni HM, Ding WX, Jaeschke $\mathrm{H}$ (2013) Receptor interacting protein kinase 3 is a critical early mediator of acetaminophen-induced hepatocyte necrosis in mice. Hepatology 58(6):2099-2108. doi:10.1002/hep.26547

Ramaiahgari SC, den Braver MW, Herpers B, Terpstra V, Commandeur JN, van de Water B, Price LS (2014) A 3D in vitro model of differentiated HepG2 cell spheroids with improved liver-like properties for repeated dose high-throughput toxicity studies. Arch Toxicol 88(5):1083-1095. doi:10.1007/s00204-014-1215-9

Reif R (2014a) Concepts of predictive toxicology. EXCLI J 13:1292-1294

Reif R (2014b) The body-on-a-chip concept: possibilities and limitations. EXCLI J 13:1283-1285

Rempel E, Hoelting L, Waldmann T, Balmer NV, Schildknecht S, Grinberg M, Das Gaspar JA, Shinde V, Stöber R, Marchan R, van Thriel C, Liebing J, Meisig J, Blüthgen N, Sachinidis A, Rahnenführer J, Hengstler JG, Leist M (2015) A transcriptomebased classifier to identify developmental toxicants by stem cell testing: design, validation and optimization for histone deacetylase inhibitors. Arch Toxicol 89(9):1599-1618. doi:10.1007/ s00204-015-1573-y

Rodrigues AV, Rollison HE, Martin S, Sarda S, Schulz-Utermoehl T, Stahl S, Gustafsson F, Eakins J, Kenna JG, Wilson ID (2013) In vitro exploration of potential mechanisms of toxicity of the human hepatotoxic drug fenclozic acid. Arch Toxicol 87(8):1569-1579. doi:10.1007/s00204-013-1056-y

Saito C, Lemasters JJ, Jaeschke H (2010) c-Jun N-terminal kinase modulates oxidant stress and peroxynitrite formation independent of inducible nitric oxide synthase in acetaminophen hepatotoxicity. Toxicol Appl Pharmacol 246(1-2):8-17. doi:10.1016/j. taap.2010.04.015
Sanchez-Niño MD, Poveda J, Sanz AB, Carrasco S, Ruiz-Ortega M, Selgas R, Egido J, Ortiz A (2014) 3,4-DGE is cytotoxic and decreases HSP27/HSPB1 in podocytes. Arch Toxicol 88(3):597608. doi:10.1007/s00204-013-1181-7

Schug M, Stöber R, Heise T, Mielke H, Gundert-Remy U, Godoy P, Reif R, Blaszkewicz M, Ellinger-Ziegelbauer H, Ahr HJ, Selinski S, Günther G, Marchan R, Blaszkewicz M, Sachinidis A, Nüssler A, Oberemm A, Hengstler JG (2013) Pharmacokinetics explain in vivo/in vitro discrepancies of carcinogen-induced gene expression alterations in rat liver and cultivated hepatocytes. Arch Toxicol 87(2):337-345. doi:10.1007/s00204-012-0999-8

Schyschka L, Sánchez JJ, Wang Z, Burkhardt B, Müller-Vieira U, Zeilinger K, Bachmann A, Nadalin S, Damm G, Nussler AK (2013) Hepatic 3D cultures but not 2D cultures preserve specific transporter activity for acetaminophen-induced hepatotoxicity. Arch Toxicol 87(8):1581-1593. doi:10.1007/s00204-013-1080-y

Singh Y, Braeuning A, Schmid A, Pichler BJ, Schwarz M (2013) Selective poisoning of Ctnnb1-mutated hepatoma cells in mouse liver tumors by a single application of acetaminophen. Arch Toxicol 87(8):1595-1607. doi:10.1007/s00204-013-1030-8

Sisnaiske J, Hausherr V, Krug AK, Zimmer B, Hengstler JG, Leist M, van Thriel C (2014) Acrylamide alters neurotransmitter induced calcium responses in murine ESC-derived and primary neurons. Neurotoxicology 43:117-126. doi:10.1016/j.neuro.2014.03.010

Sjogren AK, Liljevald M, Glinghammar B, Sagemark J, Li XQ, Jonebring A, Cotgreave I, Brolén G, Andersson TB (2014) Critical differences in toxicity mechanisms in induced pluripotent stem cell-derived hepatocytes, hepatic cell lines and primary hepatocytes. Arch Toxicol 88(7):1427-1437. doi:10.1007/ s00204-014-1265-z

Williams CD, Farhood A, Jaeschke H (2010) Role of caspase-1 and interleukin-1beta in acetaminophen-induced hepatic inflammation and liver injury. Toxicol Appl Pharmacol 247(3):169-178. doi:10.1016/j.taap.2010.07.004

Zellmer S, Schmidt-Heck W, Godoy P, Weng H, Meyer C, Lehmann T, Sparna T, Schormann W, Hammad S, Kreutz C, Timmer J, von Weizsäcker F, Thürmann PA, Merfort I, Guthke R, Dooley S, Hengstler JG, Gebhardt R (2010) Transcription factors ETF, E2F, and SP-1 are involved in cytokine-independent proliferation of murine hepatocytes. Hepatology 52(6):2127-2136

Zimmer B, Pallocca G, Dreser N, Foerster S, Waldmann T, Westerhout J, Julien S, Krause KH, van Thriel C, Hengstler JG, Sachinidis A, Bosgra S, Leist M (2014) Profiling of drugs and environmental chemicals for functional impairment of neural crest migration in a novel stem cell-based test battery. Arch Toxicol 88(5):1109-1126 